\title{
Effect of mebendazole on fibrosarcoma in hamsters
}

\author{
Dušica J Popović ${ }^{*}$, Dušan Lalošević ${ }^{1}$, Kosta J Popović ${ }^{2}$, Ivan Čapo ${ }^{1}$, Jovan K \\ Popović $^{3}$ and Dejan Miljković ${ }^{1}$ \\ ${ }^{1}$ Department of Histology and Embryology, ${ }^{2}$ Department of Pharmacy, ${ }^{3}$ Department of Pharmacology, Toxicology and Clinical \\ Pharmacology, Faculty of Medicine, University of Novi Sad, Novi Sad, Republic of Serbia
}

*For correspondence: Email: jovan.popovic@mf.uns.ac.rs

\begin{abstract}
Purpose: To investigate the effect of mebendazole on an in vivo solid tumor model of fibrosarcoma in hamsters.

Methods: 24 Syrian golden hamsters of both sexes with the approximate body weight of $100 \mathrm{~g}$ were randomly distributed in 2 experimental and 2 control groups, with 6 animals in each group. BHK-21/C13 cells $\left(2 \times 10^{6}\right)$ in $1 \mathrm{~mL}$ Glasgow Minimum Essential Medium (GMEM) were injected subcutaneously into the back of each animal in 3 groups. The experimental groups were treated with mebendazole (460 $\mathrm{mg} / \mathrm{kg}$ ) via a gastric tube on a daily basis, immediately after tumor inoculation. In addition, one experimental group received deoxycholic acid $20 \mathrm{mg} / \mathrm{kg}$ once a day. After 2 weeks, when the tumors were approximately $1-2 \mathrm{~cm}$ in the control group, all the animals were sacrificed, and their blood collected for laboratory analysis. The tumors were excised, their weight and diameters measured, and the volumes calculated. The tumor samples were histopathologically assessed and the main organs toxicologically analyzed. Images were taken and processed by an imaging software, and Ki-67-positive cells in the tumor samples were quantified.

Results: Mebendazole diminished tumor mitosis from $18.5 \pm 3.02$ to $13.5 \pm 3.45(p<0.05)$, vasculature and tissue penetration, and increased necroses in tumor slices. Tumor volume and weight were insignificantly attenuated. Toxicity was not observed.

Conclusion: Mebendazole might be an effective non-toxic agent in sarcoma therapy.
\end{abstract}

Keywords: Mebendazole, Hamsters, BHK-21/C13 cells, Fibrosarcoma therapy, Tumor mitosis

Tropical Journal of Pharmaceutical Research is indexed by Science Citation Index (SciSearch), Scopus, International Pharmaceutical Abstract, Chemical Abstracts, Embase, Index Copernicus, EBSCO, African Index Medicus, JournalSeek, Journal Citation Reports/Science Edition, Directory of Open Access Journals (DOAJ), African Journal Online, Bioline International, Open-J-Gate and Pharmacy Abstracts

\section{INTRODUCTION}

Published results of preclinical investigations show that mebendazole, a registered antiparasitic drug widely used in endemic tropical regions, is effective against cancer cell proliferation. Clinical trials of mebendazole's anticancer effect have not yet been completed. [1]. Mebendazole exhibits anticancer activity on: osteosarcoma and soft tissue sarcoma [2]; melanoma $[3,4]$; meduloblastoma $[5,6]$; glioblastoma multiforme [7]; acute myeloid leukaemia [8,9]; lung [10], breast [11], hepatocellular [12] colorectal [2,13,14], adrenocortical [15,16], and ovarian [17] carcinoma.

Although mebendazole has shown a significant antiproliferative effect in vitro, its therapeutic antitumor value in vivo is still uninvestigated and the mechanism of action has not been clarified jet. Only a few papers have been published about mebendazole's anticancer effect on solid tumors, including sarcomas, in experimental animals. Therefore, the aim of this study is to investigate if mebendazole (given alone or in 
combination with deoxycholic acid), can suppress fibrosarcoma growth in hamsters.

BHK (Baby Hamster Kidney) cells were used in our study. The primary cultures from which the Syrian hamster fibroblast cell line BHK-21 was produced were prepared in March 1961 from the kidneys of 5 one-day-old hamsters from litter No. 21. Nineteen days after a change in growth rate was first observed, 8 clones were grown from single cells in a small drop of medium under mineral oil. One of these designated BHK-21/13 (or C13) cells has been extensively examined and is the source of the majority of BHK cells distributed in laboratories all over the world. Rapid growth and high cloning efficiency of BHK$21 / \mathrm{C} 13$ cells combined with low chromosome numbers make them especially suitable for various preclinical experiments [18].

The BHK-21 line of Syrian hamster fibroblasts is widely used for research on viruses and neoplastic cell transformations in vitro [19-22]. Some BHK-21 clones (for example C-13) induce hamster tumors [22]. As previously described in the literature [22,23], BHK cells are capable of both reproducing themselves in hamster tissues and provoking tumors.

Subcutaneous (s.c.) inoculation of $10^{7}$ BHK-21 clone 13 cells produced a fibrosarcoma that killed the hamsters in the forty day span [22].

\section{EXPERIMENTAL}

\section{Animal model}

The study was carried out on 24 adult Syrian golden hamsters about 12 weeks old (approximate body weight $100 \mathrm{~g}$ ), male and female. The investigation complies with "Principles of Laboratory Animal Care" [24]. Ethical approval for the animal studies ref. No. $01-78 / 18-5$ was obtained on $26^{\text {th }}$ April 2016 by the Ethics Committee of the University of Novi Sad, Faculty of Medicine, Republic of Serbia.

The hamsters were randomised into 2 treated and 2 control groups (with 6 animals in each group). The BHK-21/C13 cell culture $\left(2 \times 10^{6}\right.$ in 1 $\mathrm{mL}$ Glasgow Minimum Essential Medium GMEM) was inoculated s.c. with an insulin syringe, at a 45 degree angle on the right side of hamsters' loin for the production of the BHK fibrosarcoma. The treatment in two experimental groups was initiated immediately after the s.c. inoculation of BHK-21/C13 cells and continued for 14 days (until tumor diameters were approximately $1-2 \mathrm{~cm}$ in the untreated control group). At the end of the experiment, all animals were sacrificed, including the second control group without tumor inoculation, which was treated with the same dose of mebendazole as the experimental groups for 14 days. The animals were sacrificed by 10 - 15 minutes prolonged anesthesia, with pentobarbital 30 $\mathrm{mg} / \mathrm{kg}$ administered intraperitoneally.

Mebendazole, suspended in pure olive oleum, was administered once a day via a gastric tube at a dose of $460 \mathrm{mg} / \mathrm{kg}$ (in $1 \mathrm{~mL}$ per $100 \mathrm{~g}$ weight). One experimental group received additional deoxycholic acid as an adjuvant, 20 $\mathrm{mg} / \mathrm{kg}$ once a day (in $1 \mathrm{~mL}$ of water per $100 \mathrm{~g}$ weight). The control group with tumors only received isovolemic vehicle $(1 \mathrm{ml} / 100 \mathrm{~g}$ per animal).

The tumors were excided after the sacrifice. Tumor weight and size were measured. Tumor volume was calculated as $L \times S^{2} / 2$ (where $L$ was the longest, and $S$ the shortest diameter). Tumor slices were analysed histopathologically and immunohistochemically (Ki-67) for the verification of tumor growth. Blood samples were collected for conventional blood tests (erythrocytes, leucocytes, lymphocytes, monocytes, granulocytes, platelets, hemoglobin, hematocrit, $\mathrm{MCV}, \mathrm{MCH}, \mathrm{MCHC}$, serum proteins, albumins, sedimentation, partial thromboplastin time). Body weights were measured for hamsters daily to evaluate possible side effects. The main organs of animals (liver, kidneys, lungs) were toxicologically analysed.

\section{Ki-67 staining}

The tumor samples were treated with methanol, $4 \%$ BSA/PBS and anti-Ki-67 pAb at $25^{\circ} \mathrm{C}$. The secondary antibody was polyclonal anti-rabbit FITC. Hoechst 33256 (Sigma) was used for nuclei counterstaining. Leica MC190HD camera was used for taking images, which were processed by software UTHSCSA Image Tools for Windows Version 3.00 [25]. The numbers of Ki-67-positive cells were counted on 20 tumor images of each animal and the mean values were determined and compared between the groups.

\section{Statistical analysis}

Mean \pm SD was calculated for experimental data. The differences between the treated and control groups of animals were determined using Student's $t$-test (for small independent samples) for tumor weight, volume, mean number of Ki-67positive cells marked on images and other measured parameters. Statistical analysis was 
performed by Statistica 13.0. Statistically significant difference was set at $p<0.05$.

\section{RESULTS}

The subcutaneous inoculation of BHK-21/C13 cells into hamsters resulted in fibrosarcoma formation at the site of injection in all inoculated animals. Treatments with mebendazole and mebendazole with deoxycholic acid significantly reduced the proliferation status of tumor cells ( $p$ $<0.05$ ), as shown by Ki-67 staining on hamster tumor sections (Table 1). In our experiment, tumor volume and weight were not significantly changed in either of the treated groups, relative to the control group $(p>0.05)$.

The histopathological evaluation of investigated tumors (Figure 1, Figure 2, Figure 3 and Figure 4) revealed reduction of vasculature, decrease of tissue penetration and expansion of necroses with mebendazole treatment.

Mebendazole treatment had a significant effect on the body weight of the animals during the course of the study (Table 1).

Table 1: Characteristics of animals and tumors in the control and mebendazole treated groups

\begin{tabular}{|c|c|c|c|c|c|c|}
\hline \multirow{2}{*}{$\begin{array}{c}\text { Hamster } \\
\text { No }\end{array}$} & \multicolumn{2}{|c|}{ Weight (g) } & \multirow{2}{*}{ Sex } & \multicolumn{3}{|c|}{ Tumor } \\
\hline & start & end & & $\begin{array}{l}\text { Weight } \\
\text { mg }\end{array}$ & $\underset{\mathrm{cm}^{3}}{\text { Volume }}$ & $\bar{X}^{\mathrm{Ki}-67}$ for 20 \\
\hline
\end{tabular}

Control group without mebendazole treatment, with inoculated tumor

\begin{tabular}{|c|c|c|c|c|c|c|}
\hline 1 & 91 & 95 & $\mathrm{~F}$ & 2060 & 1.50000 & 17 \\
\hline 2 & 105 & 117 & $\mathrm{~F}$ & 6880 & 5.00000 & 23 \\
\hline 3 & 93 & 94 & $\mathrm{~F}$ & 260 & 0.18750 & 14 \\
\hline 4 & 94 & 110 & $\mathrm{~F}$ & 1720 & 1.00000 & 20 \\
\hline 5 & 105 & 101 & M & 2910 & 2.11981 & 18 \\
\hline 6 & 97 & 95 & M & 1400 & 1.25025 & 19 \\
\hline $\bar{X}$ & 97.5 & 102 & & 2538 & 1.84293 & 18.5 \\
\hline $\pm S D$ & 6.12 & 9.51 & & 2297 & 1.67114 & 3.02 \\
\hline \multicolumn{7}{|c|}{ Control group without tumor inoculation, treated with $460 \mathrm{mg} / \mathrm{kg}$ mebendazole } \\
\hline 1 & 90 & 92 & $\mathrm{~F}$ & 0 & 0 & 0 \\
\hline 2 & 102 & 112 & M & 0 & 0 & 0 \\
\hline 3 & 100 & 110 & M & 0 & 0 & 0 \\
\hline 4 & 88 & 90 & $\mathrm{~F}$ & 0 & 0 & 0 \\
\hline 5 & 91 & 90 & $\mathrm{M}$ & 0 & 0 & 0 \\
\hline 6 & 102 & 105 & $\mathrm{~F}$ & 0 & 0 & 0 \\
\hline $\bar{X}$ & 95.50 & 99.83 & & & & \\
\hline$\pm \mathrm{SD}$ & 6.50 & 10.32 & & & & \\
\hline \multicolumn{7}{|c|}{ Treatment with $460 \mathrm{mg} / \mathrm{kg}$ mebendazole } \\
\hline 1 & 110 & 90 & $\mathrm{M}$ & 730 & 0.448 & 12 \\
\hline 2 & 116 & 86 & M & 980 & 0.567 & 13 \\
\hline 3 & 114 & 92 & $\mathrm{M}$ & 2110 & 1.608 & 14 \\
\hline 4 & 105 & 95 & $\mathrm{~F}$ & 2570 & 1.710 & 16 \\
\hline 5 & 110 & 88 & $\mathrm{~F}$ & 690 & 0.395 & 8 \\
\hline 6 & 102 & 100 & M & 3010 & 2.280 & 18 \\
\hline $\bar{X}$ & 109.5 & 91.83 & & 1682 & 1.168 & 13.5 \\
\hline $\pm S D$ & 5.25 & 5.08 & & 1012 & 0.8001 & 3.45 \\
\hline $\mathrm{p}$ (t-test) & & & & $>0.05$ & $>0.05$ & $<0.05$ \\
\hline \multicolumn{7}{|c|}{ Treatment with $460 \mathrm{mg} / \mathrm{kg}$ mebendazole and $20 \mathrm{mg} / \mathrm{kg}$ deoxycholic acid } \\
\hline 1 & 103 & 100 & $\mathrm{~F}$ & 1250 & 0.690 & 13 \\
\hline 2 & 95 & 85 & M & 3120 & 2.490 & 18 \\
\hline 3 & 110 & 98 & M & 620 & 0.377 & 8 \\
\hline 4 & 117 & 105 & $\mathrm{~F}$ & 1320 & 0.710 & 13 \\
\hline 5 & 102 & 90 & M & 765 & 0.480 & 12 \\
\hline 6 & 98 & 84 & $\mathrm{~F}$ & 2415 & 1.860 & 15 \\
\hline $\bar{X}$ & 104.2 & 93.7 & & 1582 & 1.1012 & 13.17 \\
\hline$\stackrel{ \pm S D}{\mathrm{p}(\mathrm{t} \text {-test })}$ & $\begin{array}{r}8.08 \\
>\end{array}$ & 8.60 & & $\begin{array}{c}983 \\
>\end{array}$ & $\begin{array}{l}0.8645 \\
>0.05\end{array}$ & $\begin{array}{c}3.31 \\
<0.02\end{array}$ \\
\hline
\end{tabular}




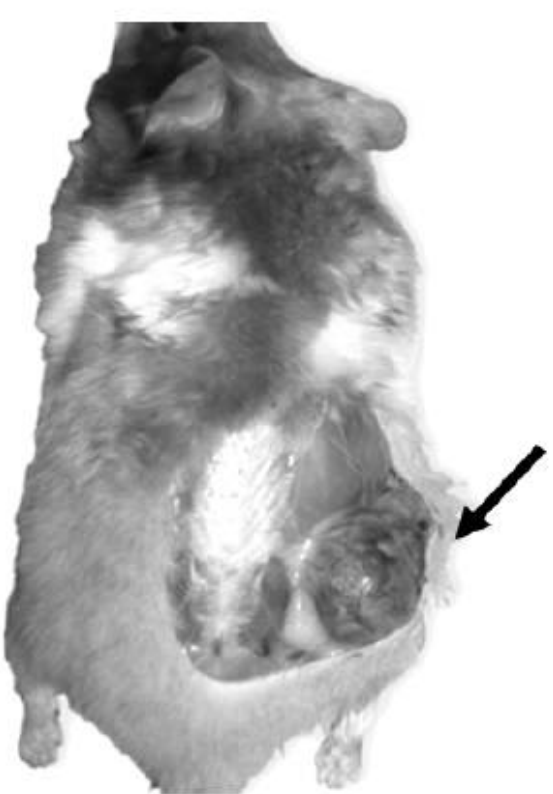

Figure 1: BHK fibrosarcoma: subcutaneous localization in a hamster
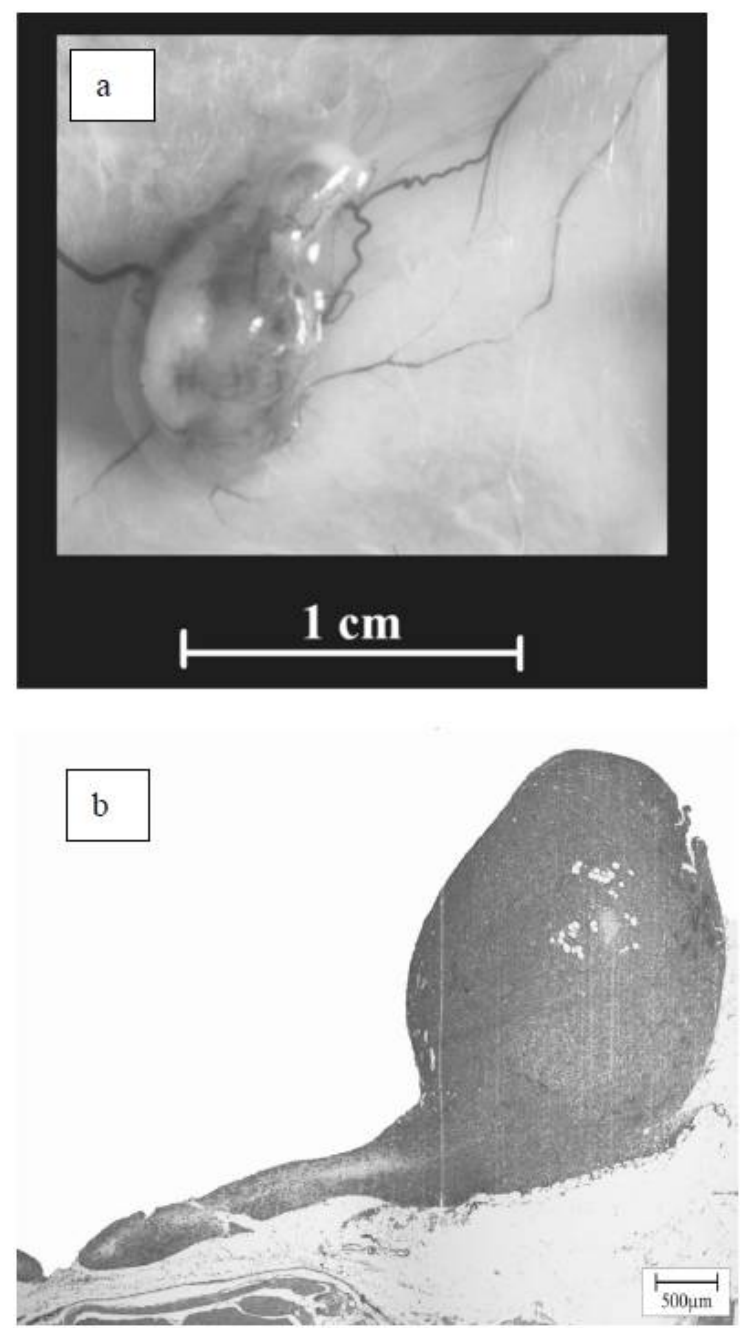

Figure 2: BHK fibrosarcoma: a) subcutaneous localization; b) hypodermal infiltration
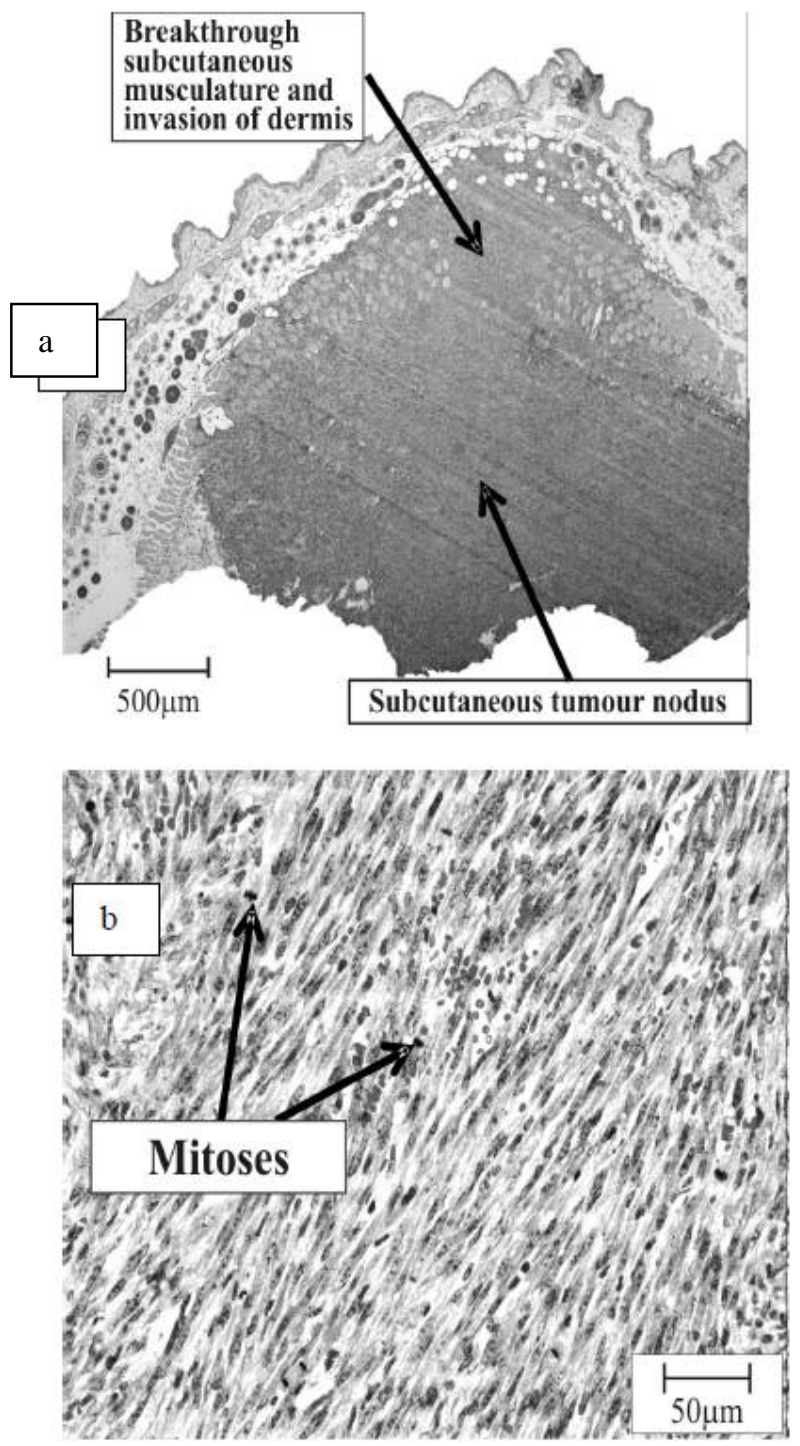

Figure 3: BHK fibrosarcoma: a) penetration into the subcutaneous musculature and the invasion of dermal structures; b) mitoses

Experimentally obtained values: the number of red and white blood cells and platelet, haemoglobin levels, hematocrit, serum proteins, sedimentation, activated partial tromboplastin time and other blood laboratory values, were statistically compared between the treated and control groups, but no significant difference was observed.

An examination of the main organs revealed no pathological or toxicological changes in the control and experimental groups.

\section{DISCUSSION}

Mebendazole has been shown to cause tubulin depolymerization in cells of various cancers $[1,8,10]$. 


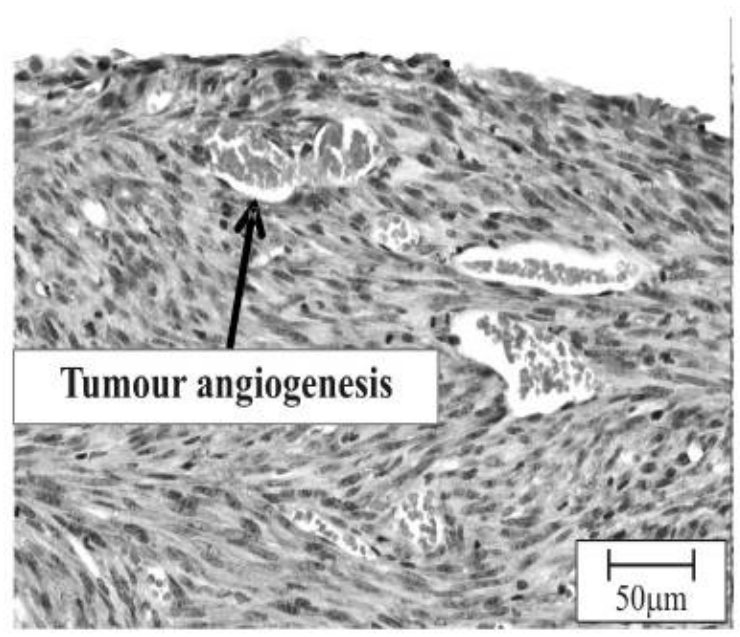

a)

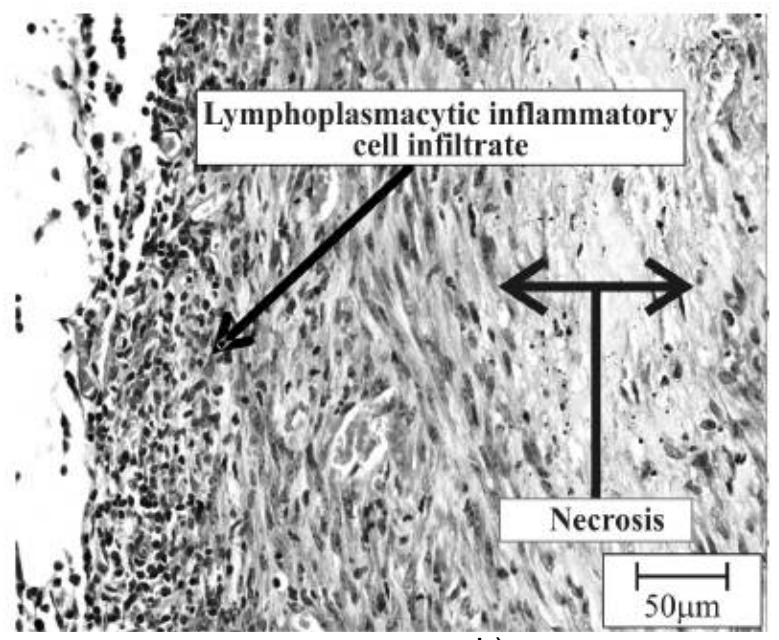

b)

Figure 4: BHK fibrosarcoma: a) tumour angiogenesis; b) lymphoplasmacytic inflammatory cell infiltration and tumour necrosis

Microtubules in the lung cancer culture were effective targets for anticancer therapy with mebendazole. This therapy blocked mitosis, induced apoptosis of lung cancer cells, activated caspase and released cytochrome c [10]. Bcl-2 inactivation is one possible explanation for mebendazole's anticancer effect on melanoma cells $[3,4]$.

In human therapeutic concentrations, mebendazole inhibits Hedgehog signaling pathway and reduces the growth of human medulloblastoma cells [26].

Like other antimicrotubular drugs, mebendazole can block tumor supply with blood by depolymerizing microtubules in tumor vasculature cells. [27]. This is in accordance with our histopathological findings on the investigated tumor vasculature.

In this experiment, histopathological improvements of the investigated tumors were observed, but we suppose that the short duration of mebendazole treatment was the main reason that the tumor volume and weight remained insignificantly changed in both treated groups. The combination with deoxycholic acid gave a slight advantage with respect to pathohistological properties probably due to better penetration of mebendazole in tissues. The verification of these preliminary results is ongoing with pretreatment (treatment before tumor inoculation), higher doses (30-50 \% $\left.\quad L_{50}\right)$, dose dependency evaluation and a longer treatment period on larger groups of experimental animals.

So far, no clinical trials on the anticancer effects of mebendazole have been completed [1].
Regarding tumour control with mebendazole therapy, only one case report of adrenocortical cancer [16] and one case report of colon cancer [14] can be found in the literature.

Future clinical trials will elucidate whether mebendazole has the potential to become an adjuvant to current antitumor and especially antisarcoma, therapies.

\section{CONCLUSION}

Since non-toxic mebendazole p.o. doses, given post-BHK21/C13 cell inoculation, inhibits sarcoma cell proliferation in hamsters, mebendazole may be a safe novel candidate for adjuvant human anti-cancer therapy. However, further investigations are required to ascertain its usefulness in a clinical setting.

\section{DECLARATIONS}

\section{Acknowledgement}

This work was supported by agencies:

- Republic of Serbia, Autonomous Province of Vojvodina, Provincial Secretariat for High Education and Scientific Research, Grant No. 142-451- 2469/2017 (JP)

- Republic of Serbia, Ministry of Science, Grants No. 171039 (JS) and 172013 (DM)

- ERASMUS + "Reinforcement of the Framework for Experimental Education in Healthcare in Serbia - ReFEEHS" Project No. 561644-EPP-1-2015-1-RS-EPPKA2-CBHEJP (2015 - 2991 / 001 -001) (JP)

Trop J Pharm Res, October 2017; 16(10): 2449 
The excellent technical assistance and suggestions during preparation of this work of electrical engineer Mrs Vesna Popović is gratefully acknowledged.

\section{Conflict of Interest}

No conflict of interest associated with this work.

\section{Contribution of Authors}

The authors declare that this work was done by the authors named in this article and all liabilities pertaining to claims relating to the content of this article will be borne by them.

\section{Open Access}

This is an Open Access article that uses a funding model which does not charge readers or their institutions for access and distributed under the terms of the Creative Commons Attribution License (http://creativecommons.org/licenses/by/ 4.0) and the Budapest Open Access Initiative (http://www.budapestopenaccessinitiative.org/rea d), which permit unrestricted use, distribution, and reproduction in any medium, provided the original work is properly credited.

\section{REFERENCES}

1. Pantziarka P, Bouche G, Meheus L, Sukhatme V, and Sukhatme VP. The repurposing drugs in oncology (ReDO) - mebendazole as an anticancer agent. Ecancermedicalscience 2014; 8: 443 [cited 2017 July 10]. Available from: https://www.ncbi.n/m.nih.gov/ pmc/articles/PMC4096024/

2. Mukhopadhyay T, Sasaki J, Ramesh R, Roth JA. Mebendazole elicits a potent antitumor effect on human cancer cell lines both in vitro and in vivo. Clin Cancer Res 2002; 8(9): 2963-2969.

3. Doudican N, Rodriguez A, Osman I, Orlow SJ. Mebendazole induces apoptosis via Bcl-2 inactivation in chemoresistant melanoma cells. Mol Cancer Res 2008; 6(8): 1308-1315.

4. Doudican NA, Byron SA, Pollock PM, Orlow SJ. XIAP downregulation accompanies mebendazole growth inhibition in melanoma xenografts. Anticancer Drugs 2013; 24(2): 181-188.

5. Bai RY, Staedtke V, Rudin CM, Bunz F, Riggins GJ. Effective treatment of diverse medulloblastoma models with mebendazole and its impact on tumor angiogenesis. Neuro Oncol 2015; 17(4): 545-554.

6. Bai RY, Staedtke $V$, Wanjiku T, Rudek MA, Joshi $A$, Gallia GL, Riggins GJ. Brain Penetration and Efficacy of Different Mebendazole Polymorphs in a Mouse Brain Tumor Model. Clin Cancer Res 2015; 21(15): 34623470.
7. Bai RY, Staedtke V, Aprhys CM, Gallia GL, Riggins GJ. Antiparasitic mebendazole shows survival benefit in 2 preclinical models of glioblastoma multiforme. Neuro Oncol 2011; 13(9): 974-982.

8. Spagnuolo $P A, H u J$, Hurren $R$, Wang $X$, Gronda $M$, Sukhai MA, Di Meo A, Boss J, Ashali I, Beheshti Zavareh $R$. et al. The antihelmintic flubendazole inhibits microtubule function through a mechanism distinct from Vinca alkaloids and displays preclinical activity in leukemia and myeloma. Blood 2010; 115(23): 48244833.

9. Shukla $N$, Kobos R, Renaud T, Steinherz LJ, Steinherz $P G$. Phase II trial of clofarabine with topotecan, vinorelbine, and thiotepa in pediatric patients with relapsed or refractory acute leukemia. Pediatr Blood Cancer 2014; 61(3): 431-435.

10. Sasaki J, Ramesh R, Chada S, Gomyo Y, Roth JA, Mukhopadhyay $T$. The anthelmintic drug mebendazole induces mitotic arrest and apoptosis by depolymerizing tubulin in non-small cell lung cancer cells. Mol Cancer Ther 2002; 1(13): 1201-1209.

11. Coyne CP, Jones T, Bear R. Gemcitabine-(C4-amide)[anti-HER2/neu] Anti-Neoplastic Cytotoxicity in Dual Combination with Mebendazole against Chemotherapeutic-Resistant Mammary Adenocarcinoma. J Clin Exp Oncol 2013; 2(2): pii: 1000109

12. Pourgholami MH, Woon L, Almajd R, Akhter J, Bowery P, Morris DL. In vitro and in vivo suppression of growth of hepatocellular carcinoma cells by albendazole. Cancer Lett 2001; 165(1): 43-49.

13. Nygren $P$, Fryknäs $M$, Agerup $B$, Larsson $R$. Repositioning of the anthelmintic drug mebendazole for the treatment for colon cancer. J Cancer Res Clin Oncol 2013; 139(12): 2133-2140.

14. Nygren P, Larsson R. Drug repositioning from bench to bedside: tumour remission by the antihelmintic drug mebendazole in refractory metastatic colon cancer. Acta Oncol 2014; 53(3): 427-428.

15. Martarelli D, Pompei P, Baldi C, Mazzoni G. Mebendazole inhibits growth of human adrenocortical carcinoma cell lines implanted in nude mice. Cancer Chemother Pharmacol 2008; 61(5): 809-817.

16. Dobrosotskaya IY, Hammer GD, Schteingart DE, Maturen KE, Worden FP. Mebendazole monotherapy and long-term disease control in metastatic adrenocortical carcinoma. Endocr Pract 2011; 17(3): e59-62.

17. Steg $A D$, Katre $A A$, Bevis KS, Ziebarth A, Dobbin ZC, Shah MM, Alvarez RD, Landen CN. Smoothened antagonists reverse taxane resistance in ovarian cancer. Mol Cancer Ther 2012; 11(7): 1587-1597.

18. Stoker M, Macpherson I. Syrian hamster fibroblast cell line BHK21 and its derivatives. Nature 1964; 203: 13551357.

19. Lalosević D, Stankov S, Lazarević-Ivanc L, Lalosević V, Knezević I. Immunogenicity of BHK-rabies vaccine in human volunteers. Med Pregl 1998; 51(1): 17-19.

Trop J Pharm Res, October 2017; 16(10): 2450 
20. Shipman C, Vander Weide GC, Ma BI. Prevalence of type $R$ virus-like particles in clones of BHK-21 cells. Virology 1969; 38: 707-710.

21. Walker TA, Wilson BA, Lewis AM, Cook JL. E1A oncogene induction of cytolytic susceptibility eliminates sarcoma cell tumorigenicity. Proc Natl Acad Sci U S A 1991; 88(15): 6491-6495.

22. Mayo J, Lombardo J.L, Klein-Szanto AJP, Conti C J, Moreira JL. An Oncogenic Virus Carried by Hamster Kidney Cells. Cancer Res 1973; 33: 2273-2277.

23. Johnson TS, Scholfield CI, Parry J, Griffin M. Induction of tissue transglutaminase by dexamethasone: its correlation to receptor number and transglutaminase- mediated cell death in a series of malignant hamster fibrosarcomas. Biochem J 1998; 331(Pt 1): 105-112.

24. "Principles of Laboratory Animal Care", NIH publication no. 85-23, revised 1985.

25. Sousa ATO de, Vasconcelos JMB, Soares MJGO. Software Image Tool 3.0 as an Instrument for Measuring Wounds. English/Portuguese $J$ Nurs UFPE on line, 2012; 6(10): 2569-2573.

26. Larsen AR, Bai RY, Chung JH, Borodovsky A, Rudin CM, Riggins GJ, Bunz F. Repurposing the antihelmintic mebendazole as a hedgehog inhibitor. Mol Cancer Ther 2015; 14(1): 3-13.

27. Jordan MA, Wilson L. Microtubules as a target for anticancer drugs. Nat Rev Cancer 2004; 4(4): 253-265. 